$\mathrm{Oz}$

Volume 13

Article 3

$1-1-1991$

\title{
Triskaidekaphobia and Colonial American Land Development
}

Diane Wilk Shirvani

Follow this and additional works at: https://newprairiepress.org/oz

Part of the Architecture Commons

(c) (1) $(9$

This work is licensed under a Creative Commons Attribution-Noncommercial-No Derivative Works 4.0 License.

\section{Recommended Citation}

Shirvani, Diane Wilk (1991) "Triskaidekaphobia and Colonial American Land Development," Oz: Vol. 13. https://doi.org/10.4148/2378-5853.1215

This Article is brought to you for free and open access by New Prairie Press. It has been accepted for inclusion in Oz by an authorized administrator of New Prairie Press. For more information, please contact cads@k-state.edu. 
Triskaidekaphobia ${ }^{1}$ and Colonial American Land Development

\author{
Diane Wilk Shirvani
}

\section{Introduction}

The number 13 sparks pangs of fear, even in today's supposedly rational, non-superstitious age. What powers does this number posses? Why is it feared? What is the basis for the superstition? In honor of the 13th issue of $O z$, this paper focuses on triskaidekaphobia (fear of the number 13) and suggests that this and the related trepidations of the Pilgrims had implications for land settlement patterns in Colonial America.

What, if anything, does the superstition have to do with Colonial American land settlement? This paper proposes that triskaidekaphobia and related superstitions were a factor in the layout of villages in Colonial New England. The first part of the paper will investigate the nature and foundations of the superstitions. The remainder of the paper will show that the Pilgrims did indeed harbor these superstitions and that the superstitions very likely played a role in their conceptions of dwelling. A comparative analysis will be made between theocratic New England, where religious beliefs were strong, and the less fervent Southern colonies in an attempt to show the effect of superstitions on settlement patterns. As this is a preliminary investigation, the paper does not attempt to answer all of the questions surrounding superstition and colonial American land settlement, it is more an effort to raise questions and suggest the possible link between them.

\section{Meanings of the Number 13}

As mentioned, the number 13 carries negative connotations. So much so that there is even a phobia named after it. There are buildings where the numbering of the floors goes from 12 immediately to 14. ${ }^{2}$ Some even claim that rent on the 13th floor of office towers is typically cheaper and that you may have to sit in the 13th row of an airplane if you don't get your set assignments early enough.

The Dictionary offers no clues as to this hidden meaning. Webster's New Collegiate Dictionary defines thirteen as "See Number Table." 2 The number table defines thirteen as "13" or "XIII." 3 The New Lexicon Webster's Dictionary of the English Language-Deluxe Encyclopedic Edition is slightly more elaborate. Thirteen is defined as: " 1 . adj. Being one more than 12 (*NUMBER TABLE) 2 . n. ten plus three II the cardinal number representing this (13, XIII)." Note there is no mention of superstition or evil. ${ }^{5}$

In J. E. Cirlot's, Dictionary of Symbols, 13 isn't even a separate entry, although the numbers 1 and 12 were. Thirteen, however, is listed under the entry, "Numbers" and reads as follows:

Thirteen. Symbolic of death and birth, of beginning afresh... Hence it has unfavorable implications. [Furthermore], the first ten numbers in the Greek system [of symbolism] (or twelve in the oriental tradition) pertain to the spirit: they are entities, archetypes and symbols. The rest are the product of combinations of these basic numbers. [If, as suggested by Webster's Lexicon, 13 can be analyzed as $10+3$, then: ten in decimal systems symbolizes] a return to unity and [three], spiritual synthesis, and solution of conflict posed by dualism. It also forms a balf-circle comprising: birth, zenith and descent among other things. ${ }^{6}$

Looking "at the normal interpretation of numbers from the psychologist's point of view as they appear in the obsessions and dreams of average people," we learn that "three stands for biological synthesis, childbirth and the solution of a conflict; [and] ten in its graphic form as 10 , is sometimes used to express marriage." 7 By extrapolation, $10+3$, means: marriage, synthesis, childbirth and solution of conflict (in that order). ${ }^{8}$

Reading on in Cirlot's entry on numbers under the category of General Characteristics, thirteen again was not listed but there was an entire discourse on the number 3 which apparently holds the key to what may or may not be evil with 13 :

The dynamism and the symbolic richness of the number three is so exceptional that it cannot be over-emphasized. The reconciling function of the third element of the ternary, may appear in either a favorable or an adverse light...when in myths and legends...the third element represents the magic or miraculous solution desired and sought after; but this third element may... also be negative. ...In almost all those myths and tales the third element corresponds to death, because of the asymmetrical division of the cycle of man's life, composed of two parts which are ascending (infancyadolescence, youth-maturity) and the third and last which is descending (old age-death). ${ }^{9}$

Apparently, the crux of problem, again, with the number $13(10+3)$ has to do with the issue of death. $10+3$ is, however, more than tempered by the number 10 , or unification number, which represents rebirth after death, a positive aspect.

In addition, the 13th Tarot card used in the telling of fortunes is Death. The card represents the mystery of Death, not necessarily death itself, ${ }^{10}$ and as such, 13 is interpreted to mean "domination and strength, rebirth, creation and destruction." ${ }^{11}$ Runes are also used for the telling of fortunes. It is interesting to note that the 13th rune is Jera which means "harvest, fertile season or one year...A span of time always is involved; hence the key words "one year," symbolizing a full cycle of time before the reaping, the harvest or deliverance." 12 In many ways, the interpretation of the thirteenth rune corresponds to the interpretation of the number 13. Harvest, implying death, is also a season of plenty with the cyclical expectation of a new harvest the next year. Death is only implied by harvest and again tempered and modified by the cyclical notion of rebirth.

Over and over, it appears that this cyclical death and rebirth is repeated. Nothing, however, indicates the source of the superstition involved in these notions. To 9 
understand that aspect, one has to examine the meaning of death and rebirth further.

\section{Religious Basis of Superstition}

Pagan religions fostered the idea of recurrent cycles where death was a part of the natural cycle of growth and decline. But in some religions, the dead were said to be reborn or reincarnated into a new living being.

The older matriarchal religions were more realistic in their acceptance of death, making it the sage's duty to realize the ugliness, corruption, and decay in nature as fully as he might realize its beauty: to accord death the same value as birth. The two were of equal importance, as two passages through the same Door: one coming out, the other going in...Avalon justly remarked that in the west, the terrible beauty of such forms is not understood'; missionaries could only describe the Death-goddess as a she-devil. ${ }^{13}$

In such religions, death is a return to mother earth, darkness and unconsciousness. Death is a return to a world in which unconsciousness rules. Matriarchal religions are based on the belief in a Great Earth or Mother Goddess who gives birth to all life and takes all life back in a cyclical fashion, hence Religions that are based on Death-Rebirth, or Death/Fertility rites and worship. In religions where the emphasis is based on the attainment and preservation of consciousness, a return to unconsciousness and darkness is hence evil or bad and something to fear at all costs.

Jungian depth-psychology as interpreted by Neumann, suggests that in the development of consciousness there is a ongoing struggle with unconsciousness and a necessary suppression of it. It furthermore elaborates on the way unconsciousness is associated with matriarchal religions and feminine power and consciousness with patriarchal religions in which the female or unconscious must be suppressed in
Old versus New Religions in Medieval Europe

If we now understand the differences between matriarchal and patriarchal religions (Old versus New) and we accept that many of the Old Religions of Europe were based on a matriarchal religion, we can begin to understand some of the basis for superstition. Europe during the Middle Ages went through enormous transitions. Many areas in the countryside were still pagan and worshiped pagan goddesses and

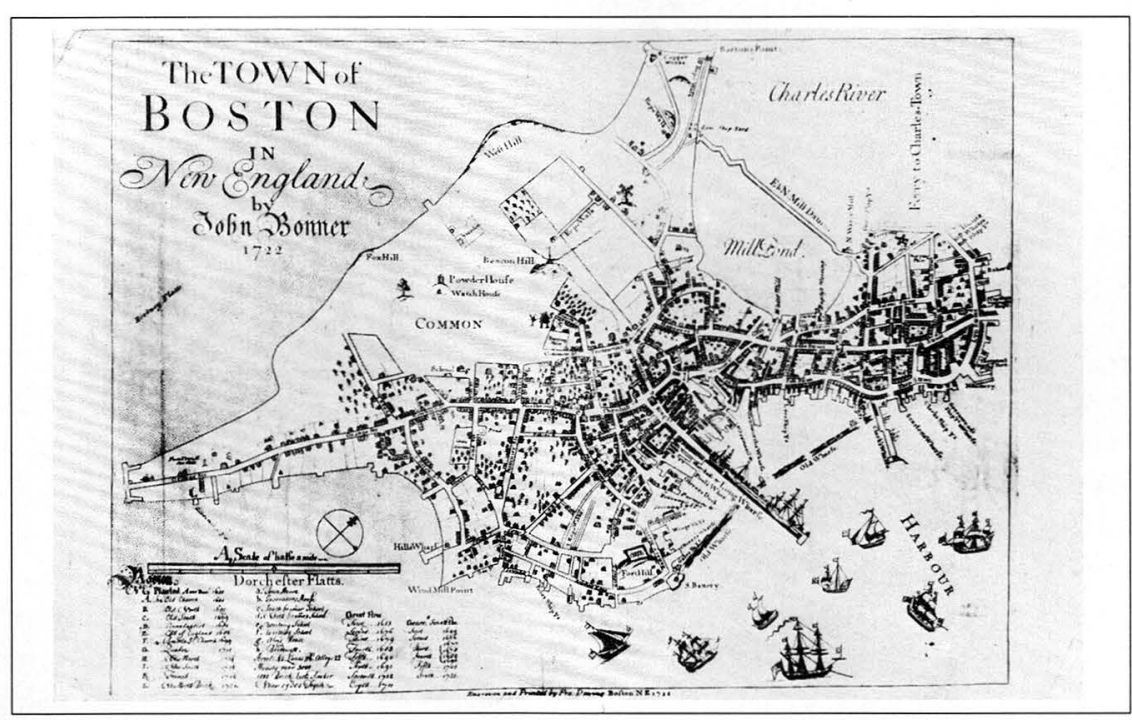

Figure 1: Medieval Boston.

gods. Sometimes despite conversion to Christianity, they incorporated much of the old religion into their new beliefs. The only way to combat the Old, was to present it as evil and to associate it with the Devil. Christianity was considered the enlightened and a more conscious way. The Old was the unconscious and hence, for reasons previously discussed, evil and the domain of Satan.

These superstitions came with settlers to New England. Many of them were Puritans or Separatists who came from Europe to escape Religious persecution. ${ }^{15}$ For example, in England in 1593, non-conforming Separatists were forced to either "stand trial for their lives or leave the country." 16 Among these Puritans were numerous Calvinists ${ }^{17}$ who according to Stilgoe, held particularly strong views re-

garding superstitions. ${ }^{18}$ It should be remembered that this was a time when there were violent disagreements among Christians, as well as continued struggles between Christians and believers of the Old Religions. The Reformation only added to religious insecurity. One almost, by default, had to take a zealous stand to defend one's beliefs.

Remember also that the New World was settled by the English in the 1600's, still a

Differences in the English Colonists of New England and the South

The English settled the Eastern Seaboard of the New World in New England, and in Virginia and South Carolina to the South. Although both groups were English in origin, their reasons for coming to the New World were very different. Those who settled in New England were religious outcasts from Europe who came for religious freedom; those in the South came who came in pursuit of worldly (not spiritual) enrichment.

Simple observation of the physical layout of colonial settlements reveals very clear differences. In very simple terms, New England can be described as being a series of individual and tightly knit towns and villages. In the South, settlement patterns were completely dispersed with towns and villages almost nonexistent at first. Why the large disparity? The answer lies in part with the conceptions that each group of settlers brought to the concept of settlement.

New England Land Settlement Patterns To the pilgrim New Englanders,

Away from the world of pious Christians lay the wilderness that bid the shadowy power of Satan and the older gods from the penetrating scrutiny of the Christian clerics. To Anglo-Saxons the words "wlyderness" identified the nest or lair of a wild beast, not the chaotic mountains or forest or rolling waste denoted by the early modern wilderness... Wilderness identified those spaces beyond human control, the spaces of bewilderment, the spaces of heathen. ${ }^{21}$
The forest and the area outside of the boundaries of their villages were "the lair of wild beasts and wilder men, where order and shaping are not, where hapless peasants are first be-wildered, then seduced into all manner of sin...Medieval peasants understood the wilderness in halfpagan, half Christian terms." ${ }^{22}$ 


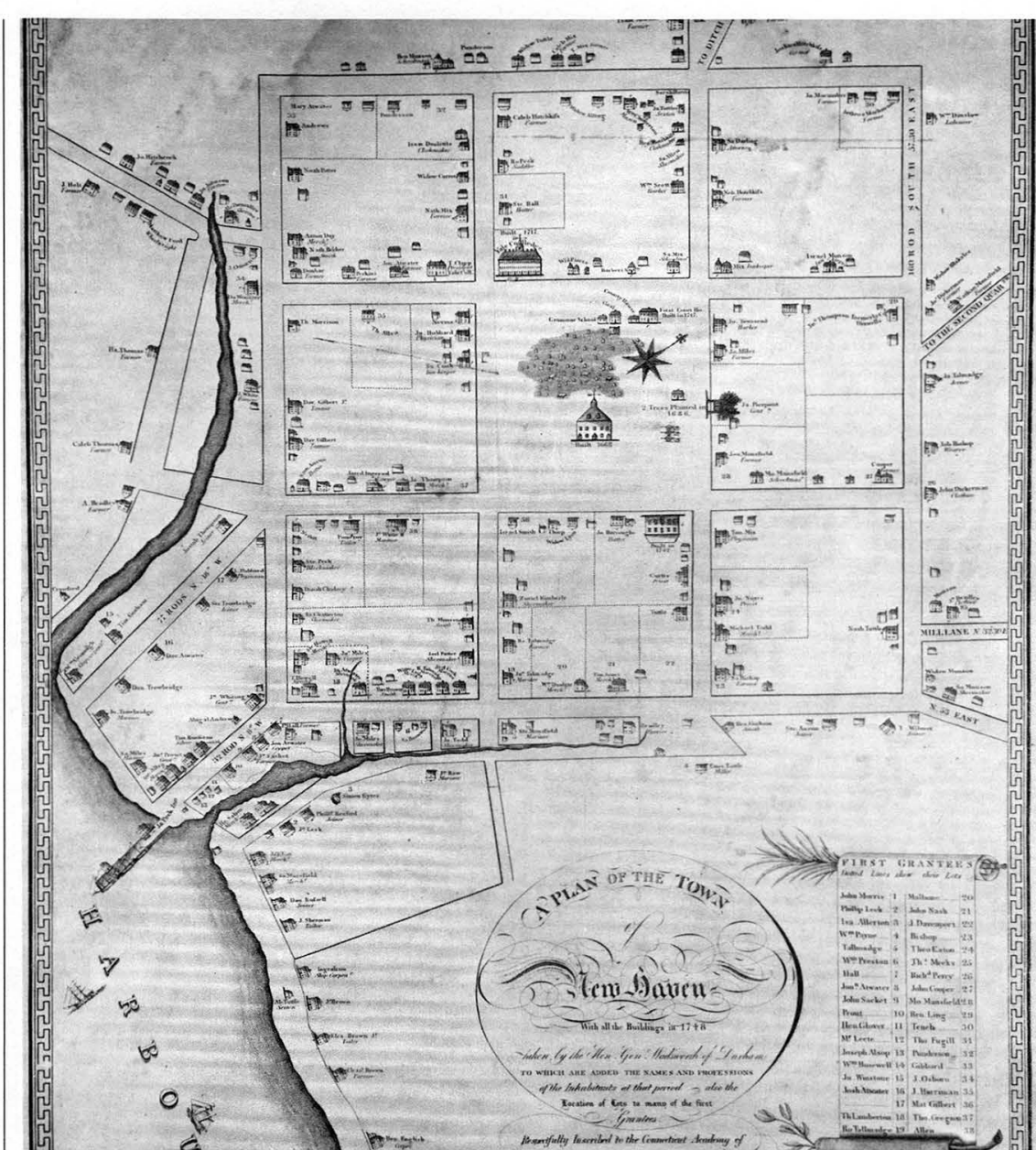

Figure 2: Plan for New Haven

Stilgoe points out that the dangers, the demons and the ghouls the occasional visitor saw in the forests were most likely, criminals who for some unspeakable crime were thrown out of the safety of the villages condemned to wander in the wilderness since there were no prisons..$^{23} \mathrm{Or}$ perhaps worshipers of the Old Religion whose ceremonies included "fertility rites, drunkenness, licentious procreation, general surrender to sexuality, and a variety of other "rogueries"; ${ }^{24}$ and wild folk whose "descriptions recorded by clerics and other examiners suggest now that many...were mentally retarded castoffs forced to subsist by hunting and robbing." ${ }^{25}$ Snow White, Hansel and Gretel, Little Red Riding Hood are all folk tales describing the horror of what lurked in the woods. The Pilgrims who came to the new world brought those memories with them and yet would have to face another new creature of the wilder- the external boundaries of the village. ${ }^{29}$ In fact in the early years of settlement, roads essentially ended at the forests edge; towns were connected by narrow paths along which only occasional travelers passed. ${ }^{30}$

The early ideal village was a group of nucleated houses surrounded by outlying fields for planting, a pattern eagerly copied from familiar English surroundings. ${ }^{31}$ The meeting house, the spiritual and political center of the town was, of course, at the center of the town as was the Common or Green. In fact, in the beginning, "no one was permitted to live more than half a mile from the meeting house; lest in the rigors of the New England winter, he should evade his social obligations as a member of the Church." ${ }^{\prime 2}$ This Common was used for military training exercises, hangings, outdoor religious ceremonies and livestock assembly. The term Common is probably more apropos than Green in the early years because the area received so much use that is was more muddy and trampled than grassy. ${ }^{33}$ Once the village grew to its allotted size, a new village would be founded nearby so as not to lose social order and control over the inhabitants. ${ }^{34}$

An interesting example of an idealized New England town is that of New Haven, Connecticut [1638] which "was to be an earthly representation of the city of God." ${ }^{35}$ The plan was conceived of as a nine-square grid at the center of which was a common area [See figure 2]. At the center of the common was the Church/ Meeting house, itself a perfect square. ${ }^{36} \mathrm{It}$ has been suggested that the plan is "a literal interpretation of the description of the New Jerusalem in Revelations:" 37 "And the city lieth foursquare, and length as breadth." ${ }^{38}$ [See figure 3] Even after New Haven developed outward, the streets kept sacred names such as: "Church, Chapel, College, Temple, Court, Crown, and Elm." ${ }^{39}$

By the mid-1650's, however, much of the tight-knit quality of the settlements had disappeared. The relaxation of religious authority and lures of economic profits by further development of land, all contributed to this dissolution of the original village settlement patterns. ${ }^{40}$ It was also around this time, when New Englanders began venturing out into the wilderness that the systematic extermination of the Indians began..$^{41}$ Could it be that in New Englanders' minds, the Indians were merely savage pagans, the equivalent of wild beasts or animals and hence treated as such.

\section{Southern Land Development Patterns}

The town was Jamestown, the year 1615. There could be no better illustration of the general rule that the prime object of settlers in a new land is to reproduce the living conditions of their old, to build themselves homes away from home, than that the first permanent British settlement in America should have row houses... The type had been developed in medieval towns where space was restricted-that is, for conditions that could only be produced artificially on the edge of the vast American continent... Reverend Hugh Jones... noted: "The habits, life, customs, computations, etc. of the Virginians are much the same as about London, which they esteem their home. ${ }^{\text {"42 }}$

This notion that Jamestown was a rebuilding of a piece of England is further reinforced by "John Donne wrote [who] to the founders of Jamestown in 1622, [that Jamestown is] to be "but the suburb of the Old World." ${ }^{33}$ Although the first settlers to Virginia may have brought with them notions of dwelling in close proximity to one another, they soon dispersed out into the land, causing a great deal of concern by the officials. There were attempts at first to control the dispersal of settlement but the geography of the area and economic gains to be had were far to much of a pull. Even the pleadings of the clergy who lamented on the lack of towns, schools and churches and warned of the evil that would befall the colonists, could not hold these settlers in towns. ${ }^{44}$ Obviously, these colonists did not fear the wilderness. In contrast to their pious $\mathrm{New}$ England counterparts, neither religion nor 
superstition appears to have been a major concern; having the good life was. ${ }^{45}$ They saw much abundance in the nature that surrounded them and used (and abused) it to their advantage. As Stilgoe reiterates:

Virginia, by all seventeenth-century accounts and by most early eighteenthcentury reports too, struck observers as a vast garden. Its breezes whispered one message over and over, seducing every wondering newcomer: "Dwell here, live plentifully, and be rich. "'46

The way land was distributed in the South also contributed to a different land development pattern than that of the North. The Virginia Company granted large acreage to each settler in early Virginia in order to encourage settlement. ${ }^{47}$ When tobacco was discovered to be such a profitable endeavor, and the cultivation of tobacco requiring ever more virgin land, the planters simply moved on when the land was exhausted and developed more and more land. As landholdings grew, slavery, which had been useless to small farmers now became an advantage for the cultivation of large tracts of land. From around 1700 to 1730 the negro slave population grew from six to thirty thousand. ${ }^{48}$ In addition, the geography of the land with its plentiful harbors made it so simple for the planter to not only grow his own crops from his plantation, but to trade directly with England by shipping and receiving goods straight from his own wharf without ever having to go to through a regional seaport. ${ }^{49}$ This self-sufficiency of the plantation owners brought about the situation where the population of the South, although boasting a population in 1770 nearly as large as all the other colonies combined, could boast no major towns or cities such as those found in New England. ${ }^{50}$ This Southern land development pattern was a peculiar manmade environment and hard to explain to outsiders, but it suited the Southerners who exploited the land-and their slaves.

Differences in Attitudes Toward the Land: North and South

Very briefly, New Englanders had kept their land and constantly renewed it partly because

12 climate was severe and fertile land was scarce, and partly because of the psychological need to live in a closed protected society away from all of the bewilderment and evil of the unknown. They were certain by leaving that comfort they would confront the Devil and loose everlasting life in Christ.

In the South where religion and superstition did not exist to the same intensity, the society was on the one hand living in nature but at the same time exploitative of nature. There must have been an implicit faith: If God (nature) made the land fertile, man could waste it; God (nature) would take care of making it fertile again The killing of the land was not considered important, there was obviously an endless amount more. The colonists here were sufficiently removed from the fear of the Old Religion so as not to fear the dangers of the wilderness (also enforced by profitable experience). Thus they did not hesitate to venture out into the unknown. Was it that their version of Christianity had given them enough confidence in their own will that they felt that they could overcome nature? Another interesting question that has not been researched in this paper is, what subtle effect, if any, did the Old Religion of the slaves have on their ways of life in the New World and on their masters beliefs and actions?

\section{Conclusion}

The first part of this paper dealt with triskaidekaphobia and related superstitions. It was found that the number 13 represented notions of cyclical death and rebirth, a fundamental idea of matriarchal religions. During the middle ages, there was a struggle between those old pagan ways and Christianity, and the old ways were seen as evil and associated with the Devil. It should come as no surprise then that Christian religious zealots, such as those who came to the New World, would harbour strong fears and superstitions regarding the old ways and that in their desire to protect themselves, even the way in which they laid out their villages was affected.

The second part of the paper deals specifically with attempting to show that this

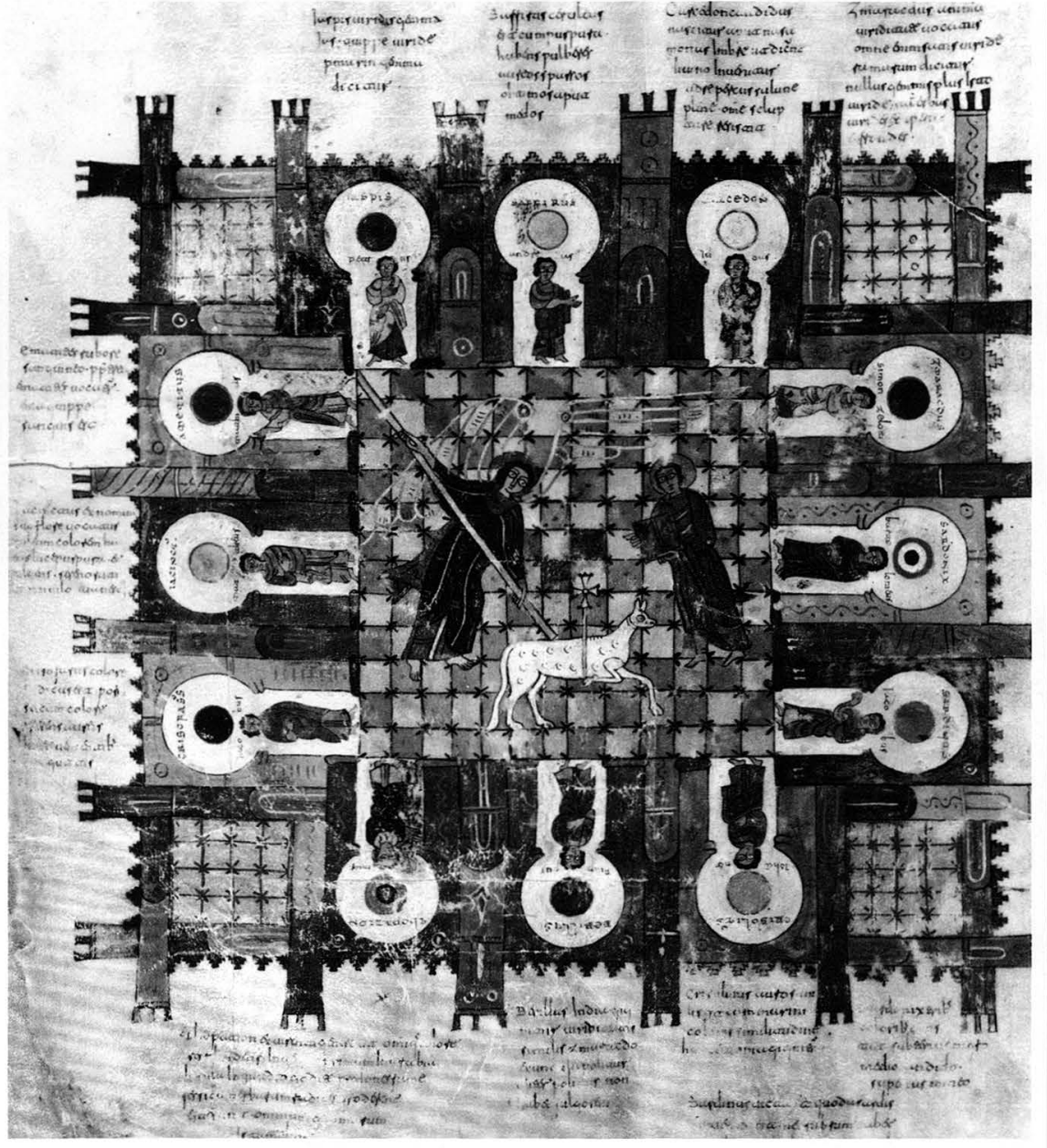

Figure 3:

fear did indeed affect settlement patterns in the New World. A comparison was made between the English settlers of the northern and southern Atlantic seaboard; the Northerners coming to the New World for religious reasons and the Southerners for monetary and material gain. The difference found in the settlement patterns in both, the New Englanders having tightly-knit villages and the Southerners unable to even to form villages suggest that fear and superstition in fact did play a role in the layout of the villages. It appears that the lure of profit and success proved to great for the Southerners to resist and that neither superstition, religion nor the laws of the government seemed to thwart their desires. Needless to say, within a few generations, this same lure overcame the New Englanders and with the loosening of the restrictions of the theocracy, her popula- tion too dispersed..$^{51}$

There are still many questions left unanswered by this study. While a case can be made for the affect of superstitions on the layout of villages, did superstition affect the architecture itself? How did superstition affect daily life? Were there any affects of superstition in the south? Did religion of the slaves form Africa have an effect on the attitudes of the English in the South? And most importantly, are these superstitions still an operative today? This paper simply introduces the possibility of a relationship between superstition and settlement patterns. Answers to these and other questions are yet to be discovered. 
1. Triskaidekaphobia, also spelled tridecaphobia and tredecaphobia, meaning fear of the number 13 or fear of having 13 people at a table. Doctor Ronald M. and Ada P. Kahn (1989). Encyclopedia of Phobias and Anxieties New York: Facts on File. p. 407.

2. An interesting example of this, and probably just one of many, is the now defunct Catholic hospital Queen of Angeles in Los Angeles. The 13th floo simply did not exist. Just in case people caught on to the numbering game, no patients actually ever had to stay for any length of time on the renumbered 14 because, although most of the other floors had patient beds, the "14th" floor was the X-Ray department.

3. Webster's New Collegiate Dictionary, p. 884, G \& C. Merriam Co., Springfield, MA, 1961

4. Ibid, p. 576.

5. New Lexicon Webster's Dictionary of the English Language Deluxe Encyclopedic Edition, p. 1028 Lexicon Publications, Inc., New York, 1987.

6. J. E. Cirlot, A Dictionary of Symbols, translated from the Spanish by Jack Sage, pp. 230-237, second edition, Philosophical Library, Inc., New York, 1983

7. Ibid, p. 235-6.

8. These are things that women are told that they should celebrate, for marriage and childbirth are considered the two most important things in a women's life. Where is the "evil" in that? Perhap , only from a male perspective. Common opinion says that men hate marriage and run from it Since 13 is associated here with marriage, it again becomes a "bad" number.

9. J. E. Cirlot, A Dictionary of Symbols, p. 236-7.

10. Ibid., p. 329. See also entry under "Tarot" in Barbara G. Walker, The Woman's Encyclopedia of Myths and Secrets, pp. 976-85, Harper and Row, New York, 1983

11. Ibid, p. 330

12. Ralph Blum, The Book of Runes, $A$ Handbook for the Use of an Ancient Oracle: The Viking Runes, $\mathrm{p}$. 86, St. Martin's Press, 1982.

13. Barbara G. Walker, The Women's Encyclopedia of Myths and Secrets, p. 216. See also Arthur Avalom Shakti and Shakta, p. 171, Dover publications, Inc., New York, 1978.

14. Erich Neumann, The Origins and History of Consciousness, Bollingen Series, Princeton, 1970

15. D. W. Meinig, The Shaping of America: $A$ Geographical Perspective on 500 Years of History, Volume 1, Atlantic America, 1492-1800, p. 91, Yale University Press, New Haven, CT, 1986.

16. Ibid, p. 33

17. Ibid, p. 91

18. John R. Stilgoe, The Common Landscape of America. p. 19, Yale University Press, New Haven, CT, 1982.

19. Leland M. Roth, $A$ Concise History of American Architecture, p. 21, Harper and Row, New York 1979. Wren's plan for London dates 80 years after the first Baroque (post-Medieval, post-
Renaissance) city design of Rome for Pope Sixtus V which dates from 1585-90. See Sigfried Giedion, Space, Time and Architecture, p. 75, fifth edition, Harvard University Press, MA, 1971.

20. Leland M. Roth, A Concise History of American Architecture, p. 19.

21. John Stilgoe, The Common Landscape of America p. 10.

22. Ibid, p. 8.

23. The Pilgrims, in fact, continued the practice of banishing those who did not live up to the communal expectations to the wilderness. Only in the New World, many of the banished were not criminals, they were religious dissenters who banded together and founded their own villages by squatting. Providence and Newport, Rhode Island were both founded by such groups of dissenters and Rhode Island would eventually become a place in which religious diversity was cherished. See Meinig, The Shaping of America, $\mathrm{p}$. 93.

24. John R. Stilgoe, The Common Landscape of America, p. 18.

25. Ibid, p. 20.

26. Yi-FuTuan, Topophilia: AStudy of Environmental Perceptions, Attitudes, and Values, p. 63, PrenticeHall, Inc., Englewood Cliffs, NJ, 1974.

27. D. W. Meining, The Shaping of America. p. 33.

28. Robert A. M. Stern, Pride of Place. Building the American Dream, pp. 9-10, Houghton Mifflin Co., Boston, 1986.

29. It is interesting to note that four-fifths of the accused witches of Salem lived beyond the bounds of the Village. This fact alone made them suspect, but coupled with the fact that they were economically more successful than their Villagebound counterparts, they were prime targets for suspicion and persecution. See Stilgoe, The Common Landscape of America, p. 52-3.

30. John Stilgoe, The Common Landscape of America, p. 52

31. Ibid, p. 48. See also David Handlin, American Architecture, p. 15, Thames and Hudson, London, 1985, and Leland M. Roth, $A$ Concise History of American Architecture, p. 13.

32. Lewis Mumford, The City in History, p. 331, Harcourt, Brace and World, Inc., New York, 1961.

33. John R. Stilgoe, The Common Landscape of America, p. 48.

34. Lewis Mumford, The City in History, pp. 331-2. 35. Stern, Robert A. M. Stern, Pride of Place, p. 298

36. Vincent Scully, American Architecture and Urbanism, p. 30, new revised edition, Henry Holt and Co., 1988.

37. Robert A. M. Stern, Pride of Place, p. 298

38. Stern, Robert A. M. Stern, Pride of Place: Building the American Dream p. 298. See Bible, King James, Authorized version, Rev. 21:16.

39. Vincent Scully, American Architecture and Urbanism p. 30.

40. John R. Stilgoe, The Common Landscape of
America, p. 44.

41. Bernard Grun, The Timetables of History, p. 295 , Simon and Schuster, New York, 1982.

42. Marcus Whiffen and Frederick Koeper, American Architecture, Volume 1: 1607-1860, p. 3, second paperback edition, MIT Press, Cambridge, MA 1984.

43. Robert A. M. Stern. Pride of Place. p. 10, See John Donne, "Annual Sermon of the Reverend John Donne, Chaplin of the London Company, to the Members of that Company, 1622," Jamestown Festival Park, Virginia, plague.

44. John R. Stilgoe, The Common Landscape of America, p.69.

45. Before the plantations were owned, workers in company-owned fields who certainly did not have the Pilgrim work ethic nor the incentive for personal profit, became lazy, "learning over on their spades and hoes and...wandering about in search of the hallucinogenic plant they called Jamestown, or "Jimson' weed. Company-directed agriculture failed completely by 1616 ." See Stilgoe, p. 60.

46. John R Stilgoe, The Common Landscape of America, p. 58

47. David Handlin, American Architecture, p.15.

48. Wayne Andrews, Architecture, Ambition, and Americans: A Social History of American Architecture. p. 5, revised edition, The Free Press, A division of Macmillan Publishing Co., Inc., New York, 1978.

49. Leland M. Roth, $A$ Concise History of American Architecture. p. 24.

50. John R. Stilgoe, The Common Landscape of America, p. 83.

51. Ibid, p. 54

\section{PHOTO CREDITS}

Figure 1: "The Town of Boston in New England," by John Bonner, 1722. Courtesy of the the Map Division, The New York Public Library, Astor Lenox and TBilden Foundations.

Figure 2: Plan of the town of New Haven, Connecticut with all the buildings in 1748 by William Lyon, published by T. Kensett, 1806. Courtesy of the New-York Historical Society, N.Y.C.

Figure 3: The Heavenly Jerusalem from the Morgan Beatus. Courtesy of the Pierpont Morgan Library, New York. M.644, f.222v. 